\title{
Comparison of Post-hoc among Petty Merchants of Traditional Markets
}

\author{
Hyun Gyu Shin \\ Department of Biomedical Laboratory Science, Daegu Health College, Daegu 702-722, Korea
}

\begin{abstract}
The aim of this study undertook to ascertain the health levels and risk among petty merchants at some traditional markets by way of physical examination and laboratory tests. Data was collected through physical examination and laboratory tests on blood pressure, glucose, cholesterol, triglyceride, LDL cholesterol, and HDL cholesterol. The data was analyzed by Frequency analysis, T-test, One-Way ANOVA using the PASW statistics 18.0 program. By blood pressure on sex, male $(1.89 \pm 0.6)$, female $(1.48 \pm 0.6)$ appeared $(p<0.001)$. Male levels were higher than in female

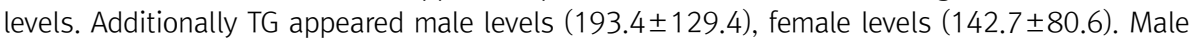
levels were higher than in female levels $(p<0.006)$. By blood pressure as the age increased in more than 70 (2.17) exhibited a statistically significant difference. These merchants did not practice health behaviors nor take institutional health management benefit. Therefore governmental level community based health management services are recommended for them.
\end{abstract}

Keywords: Traditional market, Petty merchant, Health level, Waist circumference

This is an Open Access article distributed under the terms of the Creative Commons Attribution Non-Commercial License (http://creativecommons.org/licenses/by-nc/3.0) which permits unrestricted non-commercial use, distribution, and reproduction in any medium, provided the original work is properly cited.

Copyright (@) 2014 The Korean Society for Clinical Laboratory Science. All rights reserved.
Corresponding author: Hyun Gyu Shin Department of Biomedical Laboratory Science, Daegu Health College, Daegu 702-722, Korea Tel: 82-53-320-4510

E-mail: shg8765@hanmail.net

Received: November 27, 2014 Revised: December 29, 2014 Accepted: December 29, 2014

\section{서 론}

보건수준의 향상과 의학의 발달 및 환경위생의 향상 등은 감염 병의 발생을 감소시키고 있으며, 식생활과 문화수준의 향상은 결핍 성 질병을 감소시키고 있는 반면에 만성질환 발생은 증가 일로에 있다. 일부 전통시장 상인들의 심뇌혈관질환 사망자가 해마다 발생 에 따른 불안 심리가 가중되고 있고, 구미시 보건소에 의하면 2013 년도에 일부 재래시장 상인들 건강검진실시 결과 심뇌혈관질환 고 위험군이 전체의 $11.0 \%$ 를 차지한다고 한다. 60 대 이후의 사망원인 은 암, 뇌혈관질환, 심장질환, 당뇨병, 만성하기도 질환의 순서로써 만성질환에 의한 사망이 대부분이다 $(\mathrm{Gu} \mathrm{SH}$ 등, 2010). 만성질환 중 대사증후군은 한 개인에게 복부비만, 당대사 이상, 고혈압, 이상 지혈증 등 대사적 이상소견의 집합체가 나타나는 것으로써 관상동 맥질환의 발생과 밀접한 관계가 있다(Ford, Gile \& Dietz, 2002). 최근 연구에서 대사증후군의 진단을 받은 모든 연령층의 사람들이 그렇지 않은 사람들에 비해 심혈관계 질환의 발병률은 3 배 이상 높 게 나타났다고 보고되었다(Isomaa et al, 2001). 이러한 성인의 심 혈관계 질환의 발생률을 낮추기 위해서 대사증후군을 조기발견하
고 관련요인 들을 파악하는 것이 매우 중요하다 하겠다. 급속한 고 령화 추세를 나타내고 있는 우리나라의 경우, 심뇌혈관 질환발생은 질병부담 측면에서 중요한 보건 문제로 대두되며, 선행질환인 고혈 압, 당뇨병, 고지혈증, 동맥경화증 등이 적절한 시점에서 올바른 관 리를 통해 예방될 수 있다면 심뇌혈관 질환의 경제적 질병부담을 크게 줄일 수 있다. 복부비만은 지질이상과 인슐린 저항성을 비롯 한 대사증후군을 비롯해 여러 심혈관질환과 조기사망의 위험을 증 가 시킨다고 알려져 왔다(Gerber PD 등, 1989). 총콜레스테롤과 $\mathrm{LDL}$-콜레스테롤은 관상동맥 질환의 주요 위험인자로 알려져 있 고, $\mathrm{HDL}$-콜레스테롤이 낮으면 관상동맥 질환이 증가한다고 알려 져 있다. 고혈압은 관상동맥질환과 강한 상관관계가 있고 혈압이 높을수록 그 위험은 크고 당뇨병은 관상동맥질환의 독립적인 위험 인자로서 남자에서는 2 3배, 여자에서는 3 5배 정도 관상동맥 질환의 위험이 증가한다. 비만은 독립적인 위험인자가 아니라기보 다는 비만에 의해 생기는 여러 가지 위험인자들에 의해 관상동맥 질환이 증가한다는 것을 의미한다고 할 수 있다(Chae, 2004). 전통 시장 영세상인들을 대상으로 심뇌혈관 질환 조사보고는 거의 이루 어지지 않았다. 
본 연구에서는 일부 재래시장 상인들의 심뇌혈관 질환 사망자가 지속적으로 증가함의 보고로 인해 재래시장 상인들의 건강수준을 알아보고 전통시장 건강관리 지표 개발을 위한 보건의료 지역사회 Net-work 구축의 일환으로 시도 하였다.

\section{재료 및 방법}

\section{1. 연구대상}

본 연구는 2013년 3월 20일, 28일, 29일 3일간 실시하였고, 재 료의 출처는 경상북도 구미시 보건소 건강관리계에서 구미시의 4 개소 재래시장(현대유통, 구미중앙시장, 구미상가, 제일종합상가) 의 600 개 점포상인 및 종사자 134 명 중 남자는 46 명, 여자는 88 명 을 우선대상자로 해 연구 목적을 이해하고 참여해 전통시장 건강관 리 지표 개발을 위한 보건의료 지역사회 네트워크 구축의 일환이 고, 나아가 연차별 대상 사업장 확대로 소규모 사업장 및 소상공인 심뇌혈관 질환 예방 및 건강관리 모델로 정착시키기 위한 목적도 있다.

\section{2. 연구방법}

국민건강보험공단[별첨5의 별첨]검사항목별 판정기준에 의거 (NHIC, 2012) 해서 신체계측에 해당하는 키, 체중, 허리둘레는 검 진조사를 통해 측정하였고, 체질량지수는 $\left\{\right.$ 몸무게 $(\mathrm{kg}) /\left(ㅋ \mid\left(\mathrm{m}^{2}\right)\right\}$ 를 사용해 자동 산출 되며 정상 $A$ 는 18.5 24.9 이고 정상B (경계)는 25 29.9 또는 18.5미만이고 질환의심은 30 이상으로 판정 하였 고, 허리둘레는 줄자를 이용하여 대상자 측면(mid-axillary plane) 의 마지막 늑골 하단과 장골 능선 상단의 중간 지점에서 측정하여 정상A는 남자가 90 미만, 여자는 85 미만이고, 질환의심은 남자가 90 이상, 여자 85 이상으로 판정 하였다(NHIC, 2012). 혈압은 수검 자가 최소한 5 분 이상 안정을 취한 후 수은혈압계를 이용하여 측정 하였고, 정상 $\mathrm{A}$ 가 수축기압 $120 \mathrm{mmHg}$ 미만, 이완기압은 80 $\mathrm{mmHg}$ 미만이고, 정상 $\mathrm{B}$ (경계)는 수축기압 $120 ~ 139 \mathrm{mmHg}$ 또 는 이완기압 80 89 mmHg이고, 고혈압(질환의심)은 수축기압 $140 \mathrm{mmHg}$ 이상 또는 이완기압 $90 \mathrm{mmHg}$ 이상으로 판정 하였다. 공복혈당은 8시간 이상 공복을 원칙으로 하고 정상A (100 미만), 정상 $\mathrm{B}$ (경계)(100 125), 질환의심(126 이상)으로 했고, 총콜레스 테롤은 정상 $\mathrm{A}$ (200 미만), 정상 B (200 239), 질환의심(240 이상) 으로 하고, 트리글리세라이드는 정상A (150 미만), 정상B (150 199), 질환의심(200 이상)으로 하고, LDL콜레스테롤은 정상A (130 미만), 정상B (130 159), 질환의심(160 이상)으로 하고, $\mathrm{HDL}$ 콜레스테롤은 정상 $\mathrm{A}$ (60 이상), 정상 $\mathrm{B}$ (40 59), 질환의심(40 미만)으로 판정 하였다. 국민건강보험공단의 일반건강검진 및 생
애전환기 건강진단 결과 판정기준은 정상A는 1 차검진 결과 건강이 양호한자 이고, 정상 $\mathrm{B}$ (경계)는 1차검진결과 건강에 이상이 없으나 식생활 습관, 환경개선 등 자기관리 및 예방조치가 필요한자 이고 질환의심은 1 차검진결과 질환으로 발전할 가능성이 있어 추적검 사나 전문의료기관을 통한 정확한 진단과 치료가 필요한 자로 해석 하고 있다(NHIC, 2012). 측정장비는 Hitachi 6700 (Hitachi Co., Tokyo, Japan) 자동화학 분석기를 사용하고, 혈당시약은 로슈, 콜 레스테롤, 트리글리세라이드, HDL콜레스테롤, LDL콜레스테롤 시약은 삼일제약 시약을 사용하고 공복혈당, 총콜레스테롤, $\mathrm{HDL}$ 콜레스테롤, 트리글리세라이드는 효소법으로 측정하였다. LDL콜 레스테롤은 총콜레스테롤, $\mathrm{HDL}$ 콜레스테롤, 트리글리세라이드 수 치로 계산하되, 트리글리세라이드 측정값이 $400 \mathrm{mg} / \mathrm{dL}$ 이상인 경 우 실측정 한다(기존에 채혈한 혈액을 활용).

\section{3. 통계분석}

자료분석은 PASW statistics 18.0 프로그램을 이용 하였고, 연구 대상자들의 일반적 특성은 빈도분석(Frequency analysis)을 실시 하였고, 성별에 따른 측정치를 보고 통계적으로 유의한 차이가 있는 지를 알아보기 위해 T-test 중 독립표본 평균 검정(Independent t-test)을 이용하였고, 사후검정에 의한 연령간의 차이를 알아보기 위해 일원분산분석(One-Way ANOVA)를 시행 하였다. 결과해석 시 유의수준은 $p<0.05$ 로 하였다.

\section{결 과}

\section{1. 일반적 특성}

대상자 134 명 중 남자는 46 명, 여자는 88 명이었다. 대상자들의 나이는 40 49세 21 (15.7\%), 50 59세 50 (37.3\%), 60 69세 43 (32.1\%), 70세 이상 17 (12.7\%)으로 50 59세가 $50(37.3 \%)$ 로 가 장 많았고 30 대 그룹은 $3(2.2 \%)$ 에 불과해 통계적 유의성을 갖기에 의미가 없어 보인다(Table 1). 체질량 지수는 정상A (18.5 24.9) 가 83 (61.9\%)로 대상자중 가장 많고 정상 $\mathrm{B}$ (경계) (25 29.9 또는

Table 1. Distribution of examinees by age and sex

\begin{tabular}{lccc}
\hline \multirow{2}{*}{ Age (years) } & \multicolumn{2}{c}{ Number of tests } & \multirow{2}{*}{ Total (\%) } \\
\cline { 2 - 3 } & Male & Female & \\
\hline $30 \sim 39$ & 1 & 2 & $3(2.2)$ \\
$40 \sim 49$ & 6 & 15 & $21(15.7)$ \\
$50 \sim 59$ & 17 & 33 & $50(37.3)$ \\
$60 \sim 69$ & 15 & 28 & $43(32.1)$ \\
$\geq 70$ & 7 & 10 & $17(12.7)$ \\
Total $(\%)$ & $46(34.3)$ & $88(65.7)$ & $134(100)$ \\
\hline
\end{tabular}


Table 2. Physical examination according to the age

\begin{tabular}{|c|c|c|c|c|c|c|c|c|}
\hline \multicolumn{3}{|c|}{ Variables } & \multicolumn{6}{|c|}{ Age (years) } \\
\hline & Vallantes & & \multirow{2}{*}{$\frac{30 \sim 39}{1}$} & \multirow{2}{*}{$\frac{40 \sim 49}{3}$} & \multirow{2}{*}{$\frac{50 \sim 59}{9}$} & \multirow{2}{*}{$\frac{60 \sim 69}{7}$} & \multirow{2}{*}{$\frac{\geq 70}{4}$} & \multirow{2}{*}{$\frac{\text { Total }(\%)}{24(17.9)}$} \\
\hline $\mathrm{BMI}\left(\mathrm{kg} / \mathrm{m}^{2}\right)$ & $18.5 \sim 24.9$ & Male & & & & & & \\
\hline & & Female & 1 & 13 & 22 & 18 & 5 & $59(44.0)$ \\
\hline & & Total & 2 & 16 & 31 & 25 & 9 & 83 (61.9) \\
\hline & $<18.5$ or $25 \sim 29.9$ & Male & 0 & 3 & 8 & 8 & 3 & $22(16.4)$ \\
\hline & & Female & 1 & 2 & 10 & 9 & 5 & $27(20.1)$ \\
\hline & & Total & 1 & 5 & 18 & 17 & 8 & $49(36.5)$ \\
\hline & $\geq 30$ & Male & & & & & & $0(0)$ \\
\hline & & Female & & & 1 & 1 & & $2(1.4)$ \\
\hline & & Total & & & 1 & 1 & & $2(1.4)$ \\
\hline \multirow[t]{6}{*}{ WC (cm) } & Normal A & Male & 1 & 4 & 14 & 13 & 4 & $36(26.8)$ \\
\hline & & Female & 2 & 14 & 24 & 15 & 3 & $58(43.2)$ \\
\hline & & Total & 3 & 18 & 38 & 28 & 7 & $94(70.1)$ \\
\hline & $\mathrm{R} / \mathrm{O}$ & Male & & 2 & 3 & 2 & 3 & $10(7.4)$ \\
\hline & & Female & & 1 & 9 & 13 & 7 & $30(22.3)$ \\
\hline & & Total & & 3 & 12 & 15 & 10 & $40(29.8)$ \\
\hline \multirow[t]{9}{*}{$\mathrm{BP}(\mathrm{mmHg})$} & Normal A & Male & & 4 & 4 & 5 & & $13(9.7)$ \\
\hline & & Female & 2 & 11 & 22 & 17 & 2 & $54(40.2)$ \\
\hline & & Total & 2 & 15 & 26 & 22 & 2 & $67(50.0)$ \\
\hline & Normal B & Male & 1 & 1 & 11 & 8 & 4 & $25(18.6)$ \\
\hline & & Female & & 3 & 8 & 8 & 6 & $25(18.6)$ \\
\hline & & Total & 1 & 4 & 19 & 16 & 10 & $50(37.3)$ \\
\hline & $\mathrm{R} / \mathrm{O}$ & Male & & 1 & 2 & 2 & 3 & $8(5.9)$ \\
\hline & & Female & & 1 & 3 & 3 & 2 & $9(6.7)$ \\
\hline & & Total & & 2 & 5 & 5 & 5 & 17 (12.6) \\
\hline
\end{tabular}

BMI, body mass index; BP, blood pressure; WC, waist circumference; R/O, ruled out.

18.5 미만)가 $49(36.6 \%)$ 로 나타났다(Table 2). 허리둘레는 정상A (남 90 미만, 여 85 미만)가 94 (70.1\%)이고, 질환의심(남90 이상, 여 85 이상)이 40 (29.9\%)로 나타났고, 혈압은 정상A 67 (50.0\%), 질환 의심 $17(12.7 \%)$ 로 나타났다(Table 2). 공복혈당은 질환의심(126 이 상)이 15 (11.2\%)이고, 콜레스테롤은 질환의심(240 이상)이 23 (17.2\%)로 나타났고, 중성지방은 질환의심(200 이상)이 $33(24.6 \%)$, $\mathrm{LDL}$ 콜레스테롤은 질환의심(160 이상)이 29 (21.6\%), HDL콜레스테 롤은 질환의심(40 미만) 29 (21.6\%)로 나타났다(Table 3).

\section{2. 성별에 따른 신체계측치 및 혈액검사치와의 차이 검정}

남녀 성별에 따른 연령대에서 남자의 분포가 여자의 분포에 비 해 부족한 면이 있는 것을 감안해서 해석해 보면 성별에 따른 체질 량 지수는 남자는 $24.4 \pm 2.5$, 여자는 $23.8 \pm 2.7$ 으로 남자가 여자 보다체질량지수가 약간 높게 나타났으나 통계적인 유의한 차이는 없었다( $p>0.05$ )(Table 4). 허리둘레는 남자가 $84.8 \pm 7.0$, 여자가 $81.8 \pm 8.2$ 로 나타나 통계적인 유의한 차이가 있었다 $(p<0.05)$ (Table 4). 공복혈당은 남자가 $104.6 \pm 28.3$, 여자가 $97.0 \pm 28.8$ ( $p>0.05)$, 콜레스테롤이 남자가 $205.1 \pm 35.6$, 여자가 $201.2 \pm 36.5$ ( $p>0.05)$, LDL콜레스테롤에서 남자가 $129.5 \pm 32.9$, 여자가 $128.1 \pm 37.4$ ( $p>0.05$ )로 나타나 통계적인 유의한 차이는 없었다
(Table 4). 그러나 혈압에서는 남자가 $127.8 \pm 11.5$, 여자가 $119.9 \pm 14.4$ 로 나타나 남자가 여자보다 혈압이 높게 나타나 통계 적인 유의성이 있었다 $(p<0.05)$ (Table 4$)$. 또한 중성지방 에서도 남자가 $193.4 \pm 129.4$, 여자가 $142.7 \pm 80.6$ 로 나타나 남자가 여자 보다 중성지방이 높게 나타나 통계적인 유의성이 있었다 $(p<0.05)$ (Table 4). HDL콜레스테롤 에서는 남자가 $44.5 \pm 8.4$, 여자가 $49.8 \pm 10.7$ 로 나타나 여자가 남자보다 높게 나타나 통계적으로 유 의한 차이가 있었다 $(p<0.05)$ (Table 4).

\section{3. 연령에 따른 신체계측치 및 혈액검사치와의 차이 검정}

연령에 따른 체질량지수는 30 39세(1.33 \pm 0.5$), 40 ~ 49$ 세 (1.23 \pm 0.4$), 50 \sim 59$ 세(1.40 \pm 0.5$), 60 \sim 69$ 세(1.44 \pm 0.5$), 70$ 세 이상 $(1.47 \pm 0.5)$ 로 나타나 통계적으로 차이는 없었다 $(p>0.05)$ (Table 5).

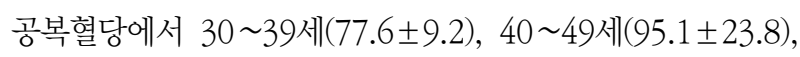

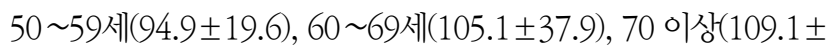
$28.8)$ 로 유의한 차이는 없었고 $(p>0.05)$, 콜레스테롤에서는 30 39세(184.3 \pm 21.9$), 40 ~ 49$ 세(195.3 \pm 38.8$), 50 ~ 59$ 세(200.9 \pm 34.0), $60 \sim 69$ (207.6 \pm 35.9$), 70$ 이상(207.0 \pm 41.7 )로 나타나 통 계적으로 유의한 차이는 없었다 $(p>0.05)$. 또한 트리글리세라이드 
Table 3. Distribution of examinees by variables

\begin{tabular}{|c|c|c|c|c|c|c|}
\hline \multirow{2}{*}{\multicolumn{2}{|c|}{ Variables }} & \multicolumn{5}{|c|}{ Age (years) } \\
\hline & & \multirow[t]{2}{*}{$30 \sim 39$} & \multirow[t]{2}{*}{$40 \sim 49$} & \multirow[t]{2}{*}{$50 \sim 59$} & \multirow[t]{2}{*}{$60 \sim 69$} & \multirow[t]{2}{*}{$\geq 70$} \\
\hline \multicolumn{2}{|l|}{ FBS (mg/dL) } & & & & & \\
\hline \multirow[t]{3}{*}{$<100$} & Male & 1 & 4 & 11 & 7 & 4 \\
\hline & Female & 2 & 12 & 26 & 16 & 5 \\
\hline & Total & 3 & 16 & 37 & 23 & 9 \\
\hline \multirow[t]{3}{*}{$100 \sim 125$} & Male & & & 4 & 6 & 1 \\
\hline & Female & & 3 & 4 & 9 & 4 \\
\hline & Total & & 3 & 8 & 15 & 5 \\
\hline \multirow[t]{3}{*}{$\geq 126$} & Male & & 2 & 2 & 2 & 2 \\
\hline & Female & & & 3 & 3 & 1 \\
\hline & Total & & 2 & 5 & 5 & 3 \\
\hline \multicolumn{7}{|c|}{ Cholesterol (mg/dL) } \\
\hline \multirow[t]{3}{*}{$<200$} & Male & 1 & 3 & 6 & 5 & 4 \\
\hline & Female & 2 & 10 & 14 & 14 & 3 \\
\hline & Total & 3 & 13 & 20 & 19 & 7 \\
\hline \multirow[t]{3}{*}{$200 \sim 239$} & Male & & 1 & 8 & 6 & 3 \\
\hline & Female & & 4 & 16 & 8 & 3 \\
\hline & Total & & 5 & 24 & 14 & 6 \\
\hline \multirow[t]{3}{*}{$\geq 240$} & Male & & 2 & 3 & 4 & \\
\hline & Female & & 1 & 3 & 6 & 4 \\
\hline & Total & & 3 & 6 & 10 & 4 \\
\hline \multicolumn{7}{|l|}{ TG (mg/dL) } \\
\hline \multirow[t]{3}{*}{$<150$} & Male & 1 & 1 & 10 & 4 & 5 \\
\hline & Female & 2 & 14 & 20 & 15 & 7 \\
\hline & Total & 3 & 15 & 30 & 19 & 12 \\
\hline \multirow[t]{3}{*}{$150 \sim 199$} & Male & & 1 & 3 & 2 & 2 \\
\hline & Female & & 1 & 5 & 6 & 2 \\
\hline & Total & & 2 & 8 & 8 & 4 \\
\hline \multirow[t]{3}{*}{$\geq 200$} & Male & & 4 & 4 & 9 & \\
\hline & Female & & & 8 & 7 & 1 \\
\hline & Total & & 4 & 12 & 16 & 1 \\
\hline \multicolumn{7}{|l|}{ LDL (mg/dL) } \\
\hline$<130$ & Male & 1 & 5 & 8 & 10 & 4 \\
\hline & Female & 1 & 9 & 15 & 17 & 3 \\
\hline & Total & 2 & 14 & 23 & 27 & 7 \\
\hline $130 \sim 159$ & Male & & & 5 & 1 & 2 \\
\hline & Female & 1 & 4 & 13 & 4 & 2 \\
\hline & Total & 1 & 4 & 18 & 5 & 4 \\
\hline$\geq 160$ & Male & & 1 & 4 & 4 & 1 \\
\hline & Female & & 2 & 5 & 7 & 5 \\
\hline & Total & & 3 & 9 & 11 & 6 \\
\hline $\mathrm{HDL}(\mathrm{mg} / \mathrm{dL})$ & & & & & & \\
\hline$\geq 60$ & Male & & 1 & 1 & & 1 \\
\hline & Female & 1 & 4 & 3 & 2 & 4 \\
\hline & Total & 1 & 5 & 4 & 2 & 5 \\
\hline $40 \sim 59$ & Male & 1 & 4 & 12 & 12 & 3 \\
\hline & Female & 1 & 10 & 24 & 17 & 4 \\
\hline & Total & 2 & 14 & 36 & 29 & 7 \\
\hline$<40$ & Male & & 1 & 4 & 3 & 3 \\
\hline & Female & & 1 & 6 & 9 & 2 \\
\hline & Total & & 2 & 10 & 12 & 5 \\
\hline
\end{tabular}

FBS, fasting blood sugar; TG, triglyceride; LDL, low density lipoprotein cholesterol; HDL, high density lipoprotein cholesterol. 
128 Hyun Gyu Shin. Comparison of Post-hoc among Petty Merchants of Traditional Markets

Table 4. Mean values of variables according to the sex

\begin{tabular}{|c|c|c|c|c|c|}
\hline \multicolumn{2}{|c|}{ Variables } & \multirow{2}{*}{$\frac{N}{46}$} & \multirow{2}{*}{$\begin{array}{c}\text { Mean } \pm \text { SD } \\
24.4 \pm 2.5\end{array}$} & \multirow{2}{*}{$\frac{t}{1.194}$} & \multirow{2}{*}{$\begin{array}{c}p \text { value } \\
0.235\end{array}$} \\
\hline BMI $\left(\mathrm{kg} / \mathrm{m}^{2}\right)$ & Male & & & & \\
\hline & Female & 88 & $23.8 \pm 2.7$ & & \\
\hline \multirow[t]{2}{*}{$W C(\mathrm{~cm})$} & Male & 46 & $84.8 \pm 7.0$ & 2.047 & $0.043^{*}$ \\
\hline & Female & 88 & $81.8 \pm 8.2$ & & \\
\hline \multirow[t]{2}{*}{$\mathrm{BP}(\mathrm{mmHg})$} & Male & 46 & $127.8 \pm 11.5$ & 3.187 & $0.001^{*}$ \\
\hline & Female & 88 & $119.9 \pm 14.4$ & & \\
\hline \multirow{2}{*}{$\mathrm{FBS}(\mathrm{mg} / \mathrm{dL})$} & Male & 46 & $104.6 \pm 28.3$ & 1.608 & 0.149 \\
\hline & Female & 88 & $97.0 \pm 28.8$ & & \\
\hline \multirow{2}{*}{$\begin{array}{l}\text { Cholesterol } \\
\text { (mg/dL) }\end{array}$} & Male & 46 & $205.1 \pm 35.6$ & 0.827 & 0.558 \\
\hline & Female & 88 & $201.2 \pm 36.5$ & & \\
\hline \multirow[t]{2}{*}{$\mathrm{TG}(\mathrm{mg} / \mathrm{dL})$} & Male & 46 & $193.4 \pm 129.4$ & 2.575 & $0.006^{*}$ \\
\hline & Female & 88 & $142.7 \pm 80.6$ & & \\
\hline \multirow[t]{2}{*}{ LDL (mg/dL) } & Male & 46 & $129.5 \pm 32.9$ & -0.648 & 0.829 \\
\hline & Female & 88 & $128.1 \pm 37.4$ & & \\
\hline \multirow[t]{2}{*}{$\mathrm{HDL}(\mathrm{mg} / \mathrm{dL})$} & Male & 46 & $44.5 \pm 8.4$ & 1.217 & $0.004^{*}$ \\
\hline & Female & 88 & $49.8 \pm 10.7$ & & \\
\hline
\end{tabular}

See Table 3. $p$-value is estimated by T-test. ${ }^{*} p<0.05$.

Table 5. Mean values of variables according to the age

\begin{tabular}{|c|c|c|c|c|c|c|}
\hline \multicolumn{2}{|c|}{ Variables } & \multirow{2}{*}{$\frac{N}{21}$} & \multirow{2}{*}{$\begin{array}{c}\text { Mean } \pm \text { SD } \\
22.8 \pm 2.6\end{array}$} & \multirow{2}{*}{$\frac{F}{0.659}$} & \multirow[t]{2}{*}{$p$ value } & \multirow[t]{2}{*}{ post-hoc } \\
\hline $\mathrm{BMI}\left(\mathrm{kg} / \mathrm{m}^{2}\right)$ & $40 \sim 49$ & & & & & \\
\hline & $50 \sim 59$ & 50 & $24.0 \pm 2.8$ & & & \\
\hline & $60 \sim 69$ & 43 & $24.4 \pm 2.3$ & & & \\
\hline & $\geq 70$ & 17 & $25.0 \pm 2.5$ & & & \\
\hline \multirow[t]{4}{*}{$W C(\mathrm{~cm})$} & $40 \sim 49$ & 21 & $78.6 \pm 6.3$ & 3.131 & $0.017^{\star}$ & $B: E$ \\
\hline & $50 \sim 59$ & 50 & $82.4 \pm 7.9$ & & & $C: E$ \\
\hline & $60 \sim 69$ & 43 & $84.0 \pm 7.4$ & & & \\
\hline & $\geq 70$ & 17 & $87.7 \pm 8.6$ & & & \\
\hline \multirow[t]{4}{*}{$\mathrm{BP}(\mathrm{mmHg})$} & $40 \sim 49$ & 21 & $118.4 \pm 18.1$ & 3.743 & $0.006^{*}$ & $B: E$ \\
\hline & $50 \sim 59$ & 50 & $120.6 \pm 13.5$ & & & $C: E$ \\
\hline & $60 \sim 69$ & 43 & $124.1 \pm 11.6$ & & & $\mathrm{D}: \mathrm{E}$ \\
\hline & $\geq 70$ & 17 & $131.2 \pm 11.9$ & & & \\
\hline \multirow[t]{4}{*}{ FBS (mg/dL) } & $40 \sim 49$ & 21 & $95.1 \pm 23.8$ & 1.437 & & \\
\hline & $50 \sim 59$ & 50 & $94.9 \pm 19.6$ & & & \\
\hline & $60 \sim 69$ & 43 & $105.1 \pm 37.9$ & & & \\
\hline & $\geq 70$ & 17 & $109.1 \pm 28.8$ & & & \\
\hline \multirow{4}{*}{$\begin{array}{l}\text { Cholesterol } \\
\text { (mg/dL) }\end{array}$} & $40 \sim 49$ & 21 & $195.3 \pm 38.8$ & 1.248 & & \\
\hline & $50 \sim 59$ & 50 & $200.9 \pm 34.0$ & & & \\
\hline & $60 \sim 69$ & 43 & $207.6 \pm 35.9$ & & & \\
\hline & $\geq 70$ & 17 & $207.0 \pm 41.7$ & & & \\
\hline \multirow[t]{4}{*}{ TG (mg/dL) } & $40 \sim 49$ & 21 & $150.7 \pm 155.5$ & 2.444 & & \\
\hline & $50 \sim 59$ & 50 & $156.8 \pm 91.8$ & & & \\
\hline & $60 \sim 69$ & 43 & $182.7 \pm 91.3$ & & & \\
\hline & $\geq 70$ & 17 & $138.2 \pm 77.1$ & & & \\
\hline \multirow[t]{4}{*}{ LDL (mg/dL) } & $40 \sim 49$ & 21 & $118.1 \pm 31.8$ & 0.979 & & \\
\hline & $50 \sim 59$ & 50 & $129.6 \pm 36.2$ & & & \\
\hline & $60 \sim 69$ & 43 & $129.6 \pm 34.2$ & & & \\
\hline & $\geq 70$ & 17 & $137.9 \pm 43.3$ & & & \\
\hline \multirow[t]{4}{*}{$\mathrm{HDL}(\mathrm{mg} / \mathrm{dL})$} & $40 \sim 49$ & 21 & $54.9 \pm 11.7$ & 2.089 & $0.003^{*}$ & $B: D$ \\
\hline & $50 \sim 59$ & 50 & $47.2 \pm 7.8$ & & & \\
\hline & $60 \sim 69$ & 43 & $44.5 \pm 8.7$ & & & \\
\hline & $\geq 70$ & 17 & $50.0 \pm 14.2$ & & & \\
\hline
\end{tabular}

See Table 3. $p$-value is estimated by One-Way ANOVA. * $p$-value $<0.05$. 


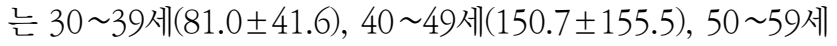

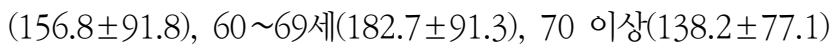
이고 LDL콜레스테롤은 $30 \sim 39$ 세(118.0 \pm 25.7$), \quad 40$ 49세

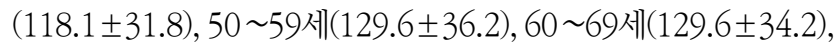
70세 이상(137.9 444.3$)$ 으로 나타나 통계적으로 유의한 차이가 없었다 $(p>0.05)$ (Table 5). 그러나 허리둘레에서 30 39세

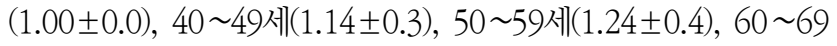
세(1.34 \pm 0.4$), 70$ 세 이상 $(1.58 \pm 0.5)$ 나타나 연령이 높아질수록 허리둘레가 커지는 것을 알 수 있고 특히 30 39세, 40 49세, 50 59세의 허리둘레와 70 세 이상의 허리둘레 간에는 통계적인 유의 한 차이가 있었다 $(p<0.05)$ (Table 5). 또한 혈압에서는 30 39세, 40 49세, 50 59세, 60 69세와 70세 이상 간에도 통계적으로 유의한 차이가 있었다 $(p<0.05)$ (Table 5).

$\mathrm{HDL}$ 콜레스테롤에서는 40 49세와 50 59세, 60 69세의 $\mathrm{HDL}$ 콜레스테롤 간에는 통계적으로 유의한 차이를 보였다 $(p$ $<0.05$ )(Table 5).

\section{4. 사후검정에 의한 그룹간의 차이 분석}

연령에 따른 체질량지수는 30 39세(1.33 \pm 0.5$), 40 ~ 49$ 세 (1.23 \pm 0.4$), 50 \sim 59$ 세(1.40 \pm 0.5$), 60 \sim 69$ 세(1.44 \pm 0.5$), 70$ 세 이상 $(1.47 \pm 0.5)$ 로 나타나 통계적으로 차이는 없었다 $(p>0.05)$ (Table 5).

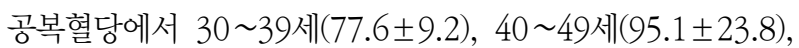

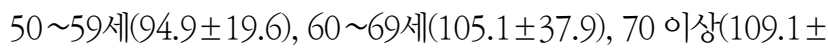
28.8)로 유의한 차이는 없었고 $(p>0.05)$, 콜레스테롤에서는 30 39세(184.3 \pm 21.9$), 40 ~ 49$ 세(195.3 \pm 38.8$), 50 ~ 59$ 세(200.9 \pm

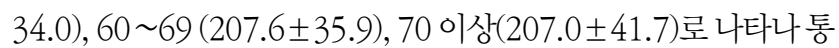
계적으로 유의한 차이는 없었다 $(p>0.05)$. 또한 트리글리세라이드

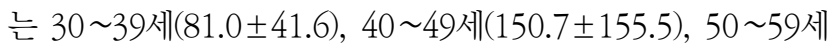

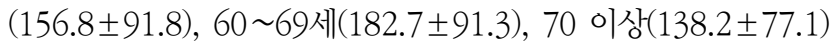
이고 LDL콜레스테롤은 30 39세(118.0 25.7), 40 49세

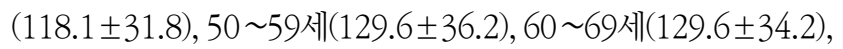
70세 이상(137.9 444.3$)$ 으로 나타나 통계적으로 유의한 차이가 없었다 $(p>0.05$ )(Table 5). 그러나 사후검정에 의한 연령간의 차이 를 알아본 결과 허리둘레는 40 대와 70 대, 50 대와 70 대 간에 유의 한 차이가 있었고(B:E, C:E) $(p<0.05)$, 혈압은 40대와 70대, 50 대 와 70대, 60 대와 70대 간에 유의한 차이가 있었다(B:E, C:E, D:E) $(p<0.05)$ (Table 5). HDL-콜레스테롤은 40대와 60 대의 연령간에 통계적으로 유의한 차이가 있었다(B:D) $(p<0.05)$ (Table 5). 30대 그룹은 $3(2.2 \%)$ 에 불과해 통계적 유의성을 갖기에 의미가 없어 보 여 제외하고 해석 하였다.

\section{고 찰}

본 연구에서는 일부 재래시장 상인 및 종사자 134 명을 우선 대상 자로 해서 대사증후군 위험요인을 분석 하였다. 우리나라는 과거에 비해서 사회적, 경제적환경이 많이 개선되었음에도 불구하고 식생 활의 서구화로 인해 영양 불균형이 심화되고 있으며 급속한 고령화 사회로 접어들면서 심혈관질환, 고혈압, 당뇨병 등 만성질환의 유 병률이 점차 증가하는 추세에 있다(Kim 등, 2004). 2001년 국민건 강영양조사에 의하면 전체인구의 약 $46 \%$ 가 연간 1 개 이상의 만성 질환을 가지고 있으며 연령이 증가할수록 그 비율이 높아져 65세 이상에서는 $86 \%$ 이상이 1 개 이상의 만성질환을 갖고 있다고 한다 (Lee, 2004). 본 연구에서도 허리둘레에서 70세 이상이 $87.7 \pm 8.6$

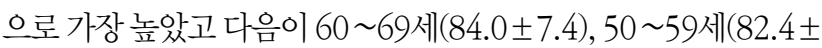
7.9), 40 49세(78.6 \pm 6.3 )으로 나타나 연령이 증가할수록 허리둘 레가 커지는 것으로 나타났고 특히 40 대, 50 대의 허리둘레와 70 대 의 허리둘레 간에는 통계적으로 유의한 차이가 있었다 $(p<0.05)$ (Table 5). HDL콜레스테롤 에서는 남자가 $44.5 \pm 8.4$, 여자가 $49.8 \pm 10.7$ 로 나타나 여자가 조금 높게 나타났고 특히 40 대와 50 대, 60 대의 $\mathrm{HDL}$ 콜레스테롤은 통계적으로 유의한 차이를 보였다 $(p<0.05)$ (Table 5). 혈중 HDL콜레스테롤의 농도와 관상동맥 질 환의 유병률 사이에 역상관 관계가 있다고 하였으며(Barr DP 등, 1951), 미국 National Cholesterol Education Program (이하 $\mathrm{NCEP}$ 로 약함)에서는 $\mathrm{HDL}-\mathrm{C}$ 농도가 $35 \mathrm{mg} / \mathrm{dL}$ 미만인 경우는 관 상동맥질환 발생의 하나의 위험인자로 정의 하였고, $60 \mathrm{mg} / \mathrm{dL}$ 이 상에서는 관상동맥질환의 발생의 음성 위험인자(negative risk factor)로 정의 하였다(The Expert Panel, 1988). 본 연구에서는 $40 \mathrm{mg} / \mathrm{dL}$ 미만인 경우는 남자가 11명, 여자가 18명으로 여자가 남 자보다 다소 많았고, $60 \mathrm{mg} / \mathrm{dL}$ 이상은 남자가 3 명, 여자가 14 명으 로 여자가 남자보다 많았다. 또한 HDL-C는 남자가 평균 44.5 $\mathrm{mg} / \mathrm{dL}$ 이고 여자는 $49.8 \mathrm{mg} / \mathrm{dL}$ 를 나타내 여자에서 높았다(Table 4). 혈압에서도 70세 이상이 $131.2 \pm 11.9$ 으로 가장 높았고, 다음

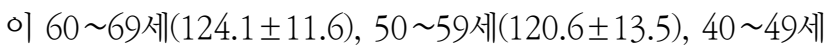
(118.4 \pm 18.1 )으로 나타났고 특히 40대, 50대, 60대와 70대 이상 의 혈압사이 에서는 통계적인 유의한 차이가 있었다 $(p<0.05)$ (Table 5). 사후검정에 의한 그룹간의 차이를 보면 허리둘레는 40 대, 50 대와 70 대 간에는 연령간에 차이가 있어서 연령이 높아질 수 록 허리둘레가 커지는 것은 음식섭취량에 비해 운동을 하지 못하는 것으로 추정되고 또한 허리둘레는 누구나 쉽게 측정도 되고 눈으로 식별도 가능해 재래시장 상인들의 심뇌혈관질환, 대사증후군을 조 기발견 하는데 유용할 것으로 사료 된다. 또한 연령이 높아질수록 혈압이 높아짐으로 아무래도 연령의 증가는 심뇌혈관질환, 고혈 
압, 당뇨병 등 만성질환의 증가에 일조할 것으로 사료 된다. 아시아/ 태평양 기준을 적용한 대사증후군의 구성요소별 유병률을 성별로 살펴보면 남자에서는 높은 혈압(70.7\%)이 가장 높고, 그 다음으로 허리둘레(55.1\%), 고중성지방혈증(51.1\%)이었고, 여자에서는 허 리둘레(73.8\%), 높은 혈압(65.5\%), 저HDL 콜레스테롤혈증 (46.9\%)순 이었다(Choi 등 2006). 본 연구에서는 혈압이 남자가 $1.89 \pm 0.6$, 여자가 $1.48 \pm 0.6$ 로 나타나 남자가 여자보다 혈압이 높은 것으로 나타났다(Table 4). 허리둘레에서는 남자가 $1.21 \pm 0.4$, 여자가 $1.34 \pm 0.4$ 로 나타나 여자가 남자보다 허리둘레가 더 큰 것 을 알 수 있다(Table 4). 최 등(2006) 연구에서는 남녀 모두에서 대 사증후군의 유병률에 가장 큰 영향을 미치는 것은 높은 혈압과 허 리둘레로 나타났다고 보고한 내용과 유사함을 알 수 있다. 그러므 로 대사증후군, 심뇌혈관질환 등의 유병률을 낮추기 위해서 관리에 역점을 두어야 할 것은 높은 혈압과 허리둘레라고 유추할 수 있다. 복부비만은 전체 체지방량과는 독립적으로 관상동맥질환의 발생 위험을 증가시킨다고 보고되고 있으며 지질이상과 인슐린저항성, 대사증후군을 비롯한 여러 심혈관계 질환과 조기사망의 위험을 증 가시킨다고 알려져 있다(Ascaso JF 등, 2003). 조사 대상자들의 연 령분포를 보면 50대, 60대가 93명으로 전체의 69.4\%를 차지해 연 령층이 비교적 높다. 근무조건이 하루종일 협소한 공간에서 새벽5 시부터 밤10시 까지 장시간 근로시간에 노출 되어 있고 자신의 건 강관리는 등한시 되고 있다. 일부 재래시장 상인들이지만 전국에 많은 재래시장 상황과 유사하다고 생각 된다. 이들에 대한 상황을 파악해서 공공보건 의료기관에서 좀 더 적극적으로 대처해 주기를 바라는 마음이다.

본 연구의 제한점은 극히 일부지역의 상인들을 대상으로 한 점 과 심뇌혈관 질환, 대사증후군 등을 판단할 수 있는 신체 계측치와 혈액검사 수치로만 연구 한 점, 30대 그룹은 $3(2.2 \%)$ 에 불과해 통 계적 유의성을 갖기에 부족한 점 등을 들 수 있다. 이런 질환들의 관 련요인을 밝혀내기 위해 흡연, 음주, 운동, 교육수준, 가족력 등 여 러 측면을 고려하지 못한 점을 아쉽게 생각 한다. 일부 지역의 상인 들을 대상으로 했지만 이들의 심뇌혈관 사망자수는 해마다 지속적 으로 증가하고 있고 발생에 따른 불안 심리가 가중되고 있다. 하루 평균 근로시간이 10.6시간으로 조사 되었고 1인1사장 체제로 건강 관리 시간이 절대적으로 부족하다. 현재 구미시 보건소 건강관리팀 을 중심으로 심뇌혈관 질환예방 및 사망률을 감소시키기 위해자투 리 시간을 활용한 건강관리, 스스로 계획하고 실천하는 건강생활 운동, 건강 새마을 운동 등을 구축하고 실행하고 있다. 앞으로 지역 보건소와 연계한 재래시장 건강관리지표를 개발하고 서로 공유하
며 예방관리를 하는 종합적이고 체계적인 대책 마련이 시급 하다고 하겠다.

Acknowledgements: None

Funding: None

Conflict of interest: None

\section{References}

1. Ascaso JF, Romero P, Real JT, Lorente RI, Martinez-Valls J, et al. Abdominal obesity, insulin resistance, and metabolic syndrome in a southern European population. Eur J Intern Med. 2003, 14:101-106.

2. Barr DP, Russ EM, Eder HA : protein-lipid relationships in human plasma II. In atherosclerosis and related conditions. AmJ Med II. 1951:480.

3. Ford ES, Giles WH, Dietz WH. Prevalence of metabolic syndrome among US adult: Finding from the third National Health and Nutrition Examination Survey. American Journal of Medicine. 2002, 287(3):356-359.

4. Gerber PD, Barrett J, Manheimer E, Whiting R, Smith R. Recognition of depressing by intermists in primary care: a comparison of internist and "gold standard" psychiatric assessments. J Gen Intern Med. 1989, 4:7-13.

5. Gu SH, Gang SU etc.. Public health. 2010, p383-394. Komoonsa, Seoul.

6. Isomaa B, Almgren P, Tuomi T, Forsen B, Lahti K, et al. Cardiovascular morbidity and mortality associated with the metabolic syndrome. 2001, 24:683-689.

7. Kim SW, Kun JH, Jun JK, Lee HK, Lee GM, et al. Association between Waist-to-height ratio and cardiovascular disease. Journal of the korean academy of family medicine. 2004, 25:740-745.

8. Lee MS, Relationship of the relative risks of the metabolic syndrome and dietary habits of middle-aged in Seoul. Korean Journal of Community Nutrition. 2004, 9(6):695-705.

9. NHIC. National Health Program. National Health Insurance Corporation. 2012, p171-173.

10. Shung Chull Chae. Risk Factors and Primary and Secondary Prevention of Coronary Heart Disease. Journal of the Korean Medical Association. 2004, 47:704-708.

11. The Expert Panel : Report of the National Cholesterol Education Program Expert Panel on Detection, Evaluation and Treatment of High Blood Cholesterol in Adults. Arch Intern Med. 1988, 148:36.

12. Young Ho Choi, Jin Young Jeong, Kyung Seob Kwak, Sung Hyun Kang, Soong Nang Jang, et al. The prevalence and Risk Factors of the Metabolic Syndrome among Local Residents Aged 45 or over in Chuncheon: Hallym Aging Study. The Journal of the Korean academy of family medicine. 2006, 27:194-198. 